\title{
Use of Information Communication Technologies Among Female Block Extension Agents in South-East Agro-Ecological Zone, Nigeria
}

\author{
Alocha, Obinna C., and Umeh, O. Ifeanyi \\ Department Of Rural Sociology And Extension, Michael Okpara University Of Agriculture, Umudike, Abia State, \\ Nigeria. \\ Correspondence E-mail:ocalocha@gmail.com; Phone:+2348063440047
}

\begin{abstract}
Block Extension Agents are the extension workers who are specifically females and who carry out Gender sensitive issues for female farmers in Nigeria. They have the objective of seeing to the extension needs of the female farmers. The study assessed the use of Information Communication Technologies (ICTs) among Block Extension Agents (BEAs) in South-East Agro-Ecological Zone of Nigeria. Multi-stage sampling technique was used in the selection of the sample for the study. Data were collected with the aid of a structured questionnaire. The data was analysed using descriptive statistics. The mean age of the respondents was 40 years. All the BEAs sampled had formal education where more than half of them (51.04\%) had first degree (B.Sc/B.Agric). The mean working experience of the respondents was 10 years. The mean income level of the respondents was $\$ 33,875$ per month. The extension agents claimed that twenty-five ICT facilities were available to them in varying degree. The attitude of the respondents towards the use of ICT facilities was positive (mean score=3.11). The extent of use of ICTs by the BEAs was low (mean score=1.45) which can be attributed to the low degree of availability of the ICTs than to their attitude towards the use of the ICT facilities. The BEAs identified thirteen (13) pressing problems that hindered their use of ICTs in varying degree and their major constraint (89.58\%) as very limited access to the internet. It is recommended that the ADPs should provide such desirable working conditions that will encourage the BEAs to put in more years of their productive service to the ADPs; Workshops, conferences and seminars should be organized to train the BEAs in the use of ICTs which will improve efficiency in their work. ICT facilities should be made available to BEAs to enhance their productivity.
\end{abstract}

Keywords: Information, Communication, Technologies, Extension-Agents, Nigeria

\section{Introduction}

The primary purpose of communication is to promote social change and economic development in nation building therefore communication is a vital tool for development and is also prominent at the emergence of the development process (Yahaya, 2003). Yahaya (2003) stressed that the success of any laudable development programme and the development of desirable social economic status depend to some extent on the communication system adopted as it is that which makes new facts, figures and opinions available to the public. Communication involves exchange of ideas, information and knowledge between one or more people with the aim of arriving at a meaning. Information as it is fondly called refers to data which facilitates the development desired in a certain field of study. It can be referred to in agriculture as innovations or ideas which are to be communicated for the desired development to effect. Without information, there will be no communication and without communication, there will be no development. Information is essential for facilitating agricultural and rural development and bringing about social and economic change. Dissemination of information using the right communication technology is very important if the receiver must make a meaning out of the message received.

The importance of Information Communication Technologies (ICTs) in the overall development of the world as a global village cannot be over emphasized. The development of ICT has encouraged the usage and accessibility of information by many people at the same time to make timely decisions (Adekoye, 2006). The accessibility to information which is mad readily available by ICTs has helped in molding our attitudes towards life including the agricultural sector (Spore, 2004). ICTs have both hardware and software components. They refer to innovations that facilitate the capturing, storage, processing, transmission and display of information by electronic means (Michleis and Van Crowder, 2001). They can be defined as a diverse set of technological tools and resources used to communicate, create, disseminate, store and manage information" (Fillip, 2000). ICTs are combinations of software and hardware and means of production that allow processing, exchange, management of knowledge and 
Use of Information Communication Technologies Among Female Block Extension Agents in South-East

information, using a range of electronic technologies which when converged on new configuration are flexible, adaptable, enabling and capable of transforming an organization" (O'Farrel, 2007). The revolution of ICTs globally has opened greater opportunity for efficient information sharing in the agricultural sector. Kiplangat (2003) stressed that ICTs have become a driving force in development, providing a means of narrowing the information gap between developed and developing countries and among their communities. It has been described as people's network that allows every user to be an information provider and knowledge sharer (Richardson, 1997). The adage "information is power" (Kintumonye, 1992) is by no means significant in the use of ICTs. Innovations / information can only be effective when there is a feedback from the audience targeted (Nwachukwu, 2003). Nwachukwu (2003) advocated that there should be a link holding the technology developers and the technology utilizers for the information to get to the targeted audience and this link is technology dissemination by the technology disseminators.

The Gender component (Women In Agriculture (WIA)) programme of ADPs in all states in Nigeria which houses the Block Extension Agents (BEAs) was introduced with the intention of increasing the well-being of women farmers in all the states' Agricultural Development Programme (ADP). Block Extension Agents are the extension workers who are mostly females and who carry out Gender sensitive issues for female farmers in Nigeria. They have the objective of seeing to the extension needs of the female farmers. These needs range from farm needs (increasing their rate and level of adoption), household needs (teaching and training the female farmers in homeeconomic activities like soap making, baking, etc) that will help fetch more income for the farmers. WIA has recorded much success both in terms of clientele coverage and in adoption rates of disseminated technologies (Odurukwe et al 2006) but the ICT facilities used by these BEAs who are the agents of this change has not being determined and answers to the following questions have not de determined: what are the ICTs available to BEAs? What is the extent of use of the ICTs by BEAs? What is the attitude of BEAs towards ICTs usage? Are there socioeconomic factors that limit BEAs usage of ICTs? What are the factors hindering the availability of ICTs to BEAs? Therefore this study tends to assess the use of ICTs among BEAs in South-East Agro-Ecological zone, Nigeria.

\section{Objectives Of The Study}

The broad objective of the study is to assess the use of ICT by block extension agents in south-east agro-ecological zone, Nigeria. The specific objectives were to:

1. determine socio-economic status of the BEAs in the states in the zone,

2. determine the ICT facilities available to the BEAs,

3. assess the attitude of BEAs towards ICTs usage,

4. determine the extent of use of ICTs by BEAs,

5. determine the constraints to the use of ICTs by BEAs.

\section{Methodology}

The study area was the South-East Agro-Ecological Zone of Nigeria. The zone lies between latitude $4^{0} 20^{\prime} \mathrm{N}$ and $7^{0} 25^{\prime} \mathrm{N}$ and longitude $5^{0} 21^{\prime} \mathrm{E}$ and $8^{0} 51^{\prime} \mathrm{E}$ and is made up of eleven (11) states namely Abia, Akwa-Ibom, Anambra, Bayelsa, Cross River, Delta, Ebonyi, Edo, Enugu, Imo, and Rivers states. The main occupation of the people of the zone is farming. The area has high potential for agriculture and is suitable for food crops, tree crops and livestock farming. Seventy percent $(70 \%)$ of the farmers in the Zone are female. The population included all the BEAs working in the states' ADPs within the South-East Agro-Ecological Zone of Nigeria. Multi-stage sampling technique was used in the selection of the study states, zones and blocks. The first stage involved the random selection of 3 states from the zone. The second stage involved selection of all agricultural zones in the selected states and the third stage involved the purposive selection of the blocks that have female BEAs which in total are 96 from the three selected states. A structured questionnaire, interview regime and Focus Group Discussion were used to collect data from the respondents. Data were analyzed using descriptive statistics.

\section{Socio-Economic Characteristics Of Respondents}

\section{Results And Discussion}

Table 1 shows the socio-economic characteristics of the female Block Extension Agents. The findings show that the mean age of the respondents was 40 years which implies that most of them are in their active years and still have more productive years to put into the extension work. Majority of them were married, had a mean household size of 7 members. 51.04\% of the BEAs from the three states' ADPs had B.Sc/B.Agric qualification. the mean working experience of the BEAs from the three states' ADPs was 10 years implying that the BEAs have had quite a lot of experience as an extension staff. In addition to this, we would say that the respondents still have more opportunities to have more extension experience if the conditions of service are good looking at their mean age of 40 
years and finally that the mean income level of the BEAs in the three states' ADPs under study was $\$ 33,875$ per month.

Table 1: Distribution Of The Respondents based on their Socio-economic characteristics

\begin{tabular}{|c|c|c|c|c|}
\hline $\begin{array}{l}\text { Characteristic } \\
\text { Age (Years) }\end{array}$ & $\begin{array}{l}\text { Akwa-Ibom } \\
\text { state Frequency }\end{array}$ & $\begin{array}{l}\text { Abia state } \\
\text { Frequency }\end{array}$ & $\begin{array}{l}\text { Imo state } \\
\text { Frequency }\end{array}$ & Total Frequency \\
\hline $26-30$ & $2(5.0)^{*}$ & - & - & $2(2.08) *$ \\
\hline $31-35$ & $6(15.0)$ & $12(41.4)^{*}$ & $7(25.9) *$ & $25(26.04)$ \\
\hline $36-40$ & $17(42.5)$ & $5(17.2)$ & $13(48.1)$ & $35(36.46)$ \\
\hline $41-45$ & $6(15.0)$ & $4(13.8)$ & $4(14.9)$ & $14(14.58)$ \\
\hline $46-50$ & $9(22.5)$ & - & $1(3.7)$ & $10(10.42)$ \\
\hline $51-55$ & - & $8(27.6)$ & $1(3.7)$ & $9(9.38)$ \\
\hline $56-60$ & - & - & $1(3.7)$ & $1(1.04)$ \\
\hline Total & $40(100)$ & $29(100)$ & $27(100)$ & $96(100)$ \\
\hline Mean & & & & A0YEARS \\
\hline Marital status & & & & \\
\hline Single & $3(7.5)^{*}$ & $5(17.2)^{*}$ & $3(11.1) *$ & $11(11.46)^{*}$ \\
\hline Married & $37(92.5)$ & $24(82.8)$ & $23(85.2)$ & $84(87.5)$ \\
\hline Widowed & - & - & $1(3.7)$ & $1(1.04)$ \\
\hline Total & $40(100)$ & $29(100)$ & $27(100)$ & $96(100)$ \\
\hline Household size (Persons) & & & & \\
\hline $1-5$ & $12(30.0)^{*}$ & $9(31.0)^{*}$ & $6(22.2)^{*}$ & $27(28.13)^{*}$ \\
\hline $6-10$ & $24(60.0)$ & $20(69.0)$ & $19(70.4)$ & $63(65.62)$ \\
\hline $11-15$ & $4(10.0)$ & - & $2(7.4)$ & $6(6.25)$ \\
\hline Total & $40(100)$ & $29(100)$ & $27(100)$ & $96(100)$ \\
\hline Mean & & & & 7 MEMBERS \\
\hline Level of formal education & & & & \\
\hline OND & $2(5.0)^{*}$ & - & $3(11.1)^{*}$ & $5(5.2)^{*}$ \\
\hline NCE & $2(5.0)$ & - & - & $2(2.08)$ \\
\hline HND & $6(15.0)$ & $20(69.0)^{*}$ & $7(25.9)$ & $33(34.38)$ \\
\hline B.Sc/B.Agric & $28(70.0)$ & $4(13.8)$ & $17(63.0)$ & $49(51.04)$ \\
\hline M.Sc & $2(5.0)$ & $5(17.2)$ & - & $7(7.3)$ \\
\hline Total & $40(100)$ & $29(100)$ & $27(100)$ & $96(100)$ \\
\hline Working Experience(Years & & & & \\
\hline $1-5$ & $3(7.5)^{*}$ & $4(13.8)^{*}$ & - & $7(7.3)^{*}$ \\
\hline $6-10$ & $26(65.0)$ & $21(72.4)$ & $15(55.6)^{*}$ & $62(64.6)$ \\
\hline $11-15$ & $6(15.0)$ & - & $7(25.9)$ & $13(13.5)$ \\
\hline $16-20$ & $4(10.0)$ & - & $5(18.5)$ & $9(9.4)$ \\
\hline $21-25$ & $1(2.5)$ & $4(13.8)$ & - & $5(5.2)$ \\
\hline Total & $40(100)$ & $29(100)$ & $27(100)$ & $96(100)$ \\
\hline Mean & & & & 10 YEARS \\
\hline Income level (\#’000) & & & & \\
\hline $10-19$ & $1(2.5)^{*}$ & $4(13.8)^{*}$ & - & $1(1.04)^{*}$ \\
\hline $20-29$ & $13(32.5)$ & $21(72.4)$ & $4(14.8) *$ & $21(21.9)$ \\
\hline $30-39$ & $23(57.5)$ & - & $18(66.7)$ & $62(64.6)$ \\
\hline $40-49$ & $2(5.0)$ & - & $5(18.5)$ & $7(7.3)$ \\
\hline $50-59$ & $1(2.5)$ & $4(13.8)$ & - & $5(5.2)$ \\
\hline Total & $40(100)$ & $29(100)$ & $27(100)$ & $96(100)$ \\
\hline Mean & & & & 33.875 \\
\hline
\end{tabular}

*Figures in parenthesis ( ) are in percentage

\section{Ict Facilities Available To Respondents}

Table 2 shows the ICT facilities available to the respondents. The respondents indicated that twenty-four ICT facilities were available to them in varying degree. From the finding, radio(96.88\%), G.S.M (93.75\%), television $(89.58 \%)$, research bulletins $(88.54 \%)$, were the ICT facilities that were readily available to the respondents in the states' ADPs under study while the availability of agricultural maps $(31.25 \%)$, media van (31.25\%), video recording (29.17\%), E-mail (27.08\%), internet (25.0\%), telephone land line (21.88\%), mobile cinema $(9.38 \%)$, data processor $(8.33 \%)$, overhead projector $(7.29 \%)$, fax $(6.25 \%)$, among BEAs under study were limited, and this may affect the usage and the purpose of use of these ICTs. 
Table 2: Distribution of Respondents By ICT Facilities Available To Them

\begin{tabular}{|c|c|c|c|c|c|}
\hline \multicolumn{2}{|c|}{ Facilities } & $\begin{array}{l}\text { Akwa-Ibom } \\
\text { Frequency }\end{array}$ & $\begin{array}{l}\text { Abia State } \\
\text { Frequency }\end{array}$ & $\begin{array}{l}\text { Imo State } \\
\text { Frequency }\end{array}$ & $\begin{array}{l}\text { Total } \\
\text { Frequency }\end{array}$ \\
\hline a) & Agricultural journals & $36(90)^{*}$ & $13(44.8)^{*}$ & $23(85.2)^{*}$ & $72(75.00)^{*}$ \\
\hline b) & Dairies & $29(72.5)$ & $9(31)$ & 21(77.8) & $59(61.46)$ \\
\hline c) & Agricultural map & $26(65)$ & - & $4(14.8)$ & $30(31.25)$ \\
\hline d) & Posters & $35(87.5)$ & $16(55.2)$ & $4(14.8)$ & $55(57.29)$ \\
\hline e) & Newsletters & $34(85)$ & $17(58.6)$ & $20(74.1)$ & $71(73.96)$ \\
\hline f) & Annual reports & $32(80)$ & $12(41.4)$ & $22(81.5)$ & $65(66.67)$ \\
\hline g) & Media van & $20(50)$ & $9(31)$ & $1(3.7)$ & $30(31.25)$ \\
\hline h) & Overhead projector & $1(2.5)$ & $5(17.2)$ & $1(3.7)$ & $7(7.29)$ \\
\hline i) & Telephone (land line) & $5(12.5)$ & $13(44.8)$ & $3(11.1)$ & $21(21.88)$ \\
\hline j) & GSM & $34(85)$ & $29(100)$ & $27(100)$ & $90(93.75)$ \\
\hline $\mathrm{k})$ & E-mail & $10(25)$ & $13(44.8)$ & $3(11.1)$ & $26(27.08)$ \\
\hline 1) & Internet & $8(20)$ & $13(44.8)$ & $3(11.1)$ & $24(25.00)$ \\
\hline m) & Radio & $37(92.5)$ & $29(100)$ & $27(100)$ & $93(96.88)$ \\
\hline n) & Television & $31(77.5)$ & $29(100)$ & $26(96.3)$ & $86(89.58)$ \\
\hline o) & Fax & $1(2.5)$ & $5(17.2)$ & - & $6(6.25)$ \\
\hline p) & Mobile cinema & $3(7.5)$ & $5(17.2)$ & $1(3.7)$ & $9(9.38)$ \\
\hline q) & Research bulletins & $32(80)$ & $29(100)$ & $24(88.9)$ & $85(88.54)$ \\
\hline r) & Data processor & $2(5)$ & $5(17.2)$ & $1(3.7)$ & $8(8.33)$ \\
\hline s) & Multimedia & $22(55)$ & $9(31)$ & $3(11.1)$ & $34(35.42)$ \\
\hline t) & Film strips & $25(62.5)$ & $8(27.6)$ & $3(11.1)$ & $36(37.50)$ \\
\hline u) & Audio cassettes & $25(62.5)$ & $9(31)$ & $5(18.5)$ & $37(38.54)$ \\
\hline v) & Video recording & $21(52.5)$ & $5(17.2)$ & $2(7.4)$ & $28(29.17)$ \\
\hline w) & Computer & $25(62.5)$ & $13(44.8)$ & $3(11.1)$ & $41(42.71)$ \\
\hline $\mathrm{x})$ & Newspapers & $37(92.5)$ & $29(100)$ & $6(22.2)$ & $72(75.00)$ \\
\hline
\end{tabular}

*Figures in parenthesis () are in percentage

\section{Attitude of Respondents Towards ICTs Usage}

Table 3 reveals the distribution of the respondents' attitude towards use of ICT facilities. It was discovered that the BEAs from the three states' ADPs under study had positive attitude towards ICTs usage as follows: ICTs provide new knowledge and information (4.23), ICTs bring about awareness and understanding of issues (3.93), ICTs increase/develop skills, abilities and competence in communication, subject matter, etc (4.01), some of the techniques required in the use of the ICTs are too technical (3.39), ICTs facilitate participation in policy making (3.22), ICTs provide access to high quality technologies (3.72), ICTs improve self confidence and self esteem (4.13), ICTs facilitate freedom to do things and express oneself (3.85), ICTs create a feeling of belonging (3.24), ICTs encourage one to take action to change one's life and that of others (3.12), ICTs provide better access to information (3.32), accepts any assignment with the use of ICTs (3.34). The BEAs in the three states' ADPs had 3.11 as their attitudinal level implying that the sampled BEAs had positive attitude towards ICTs usage and that it would not affect their use of ICTs.

\section{Extent of Use of ICTs by The Respondents}

Table 4 shows the extent of use of ICT facilities by the respondents. The respondents indicated that the ICT facilities were used by them in varying degree. The respondents from the states' ADPs under study used to a high extent radio (4.38), G.S.M (4.04) and television (3.93). The BEAs in the three states' ADPs had 1.45 as their extent of ICTs usage implying that these BEAs used the facilities to a low extent. From this finding, it would be said that the low extent of use of the ICTs by the BEAs was as a result of the few ICTs that were readily available to the BEAs than to their attitude towards the use of ICT facilities.

\section{Constraints to The Use of Icts}

Table 5 shows the constraints to use of ICTs by the respondents. The sampled BEAs from the three states' ADPs under study noted that the following were pressing problems that hindered their use of ICTs: very limited access to internet (89.58\%), unstable/unreliable electric power supply $(88.54 \%)$, inadequate source of information about the ICTs $(87.50 \%)$, limited access to computers (79.17\%), limited coverage of AM/FM stations and TV signals $(78.13 \%)$. 
Table 3: Distribution of Respondents Based on Their Attitude Towards ICTs Usage

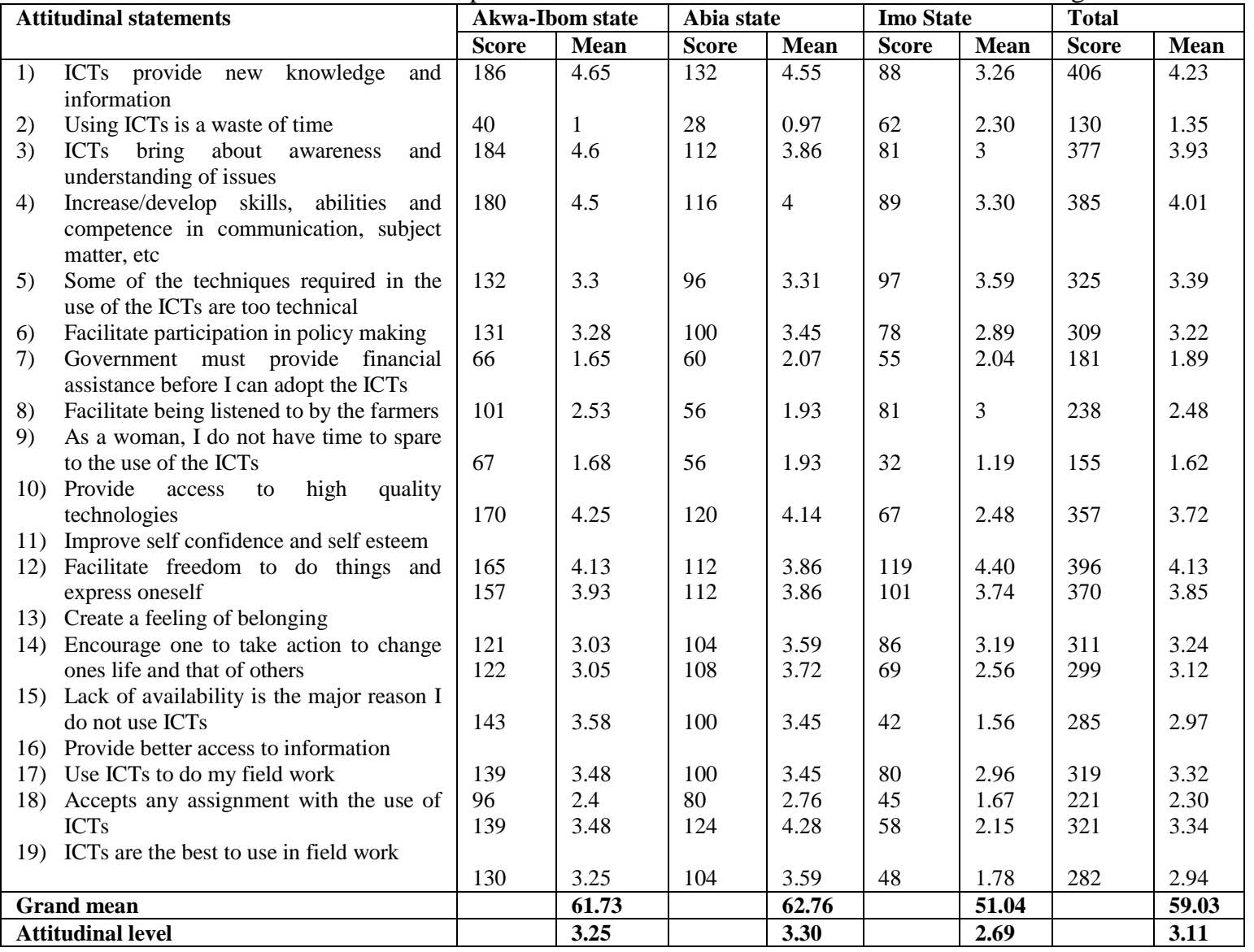

Table 4: Distribution of The Extent Of Use Of ICTs By The Respondents

\begin{tabular}{|c|c|c|c|c|c|c|c|c|c|}
\hline \multirow{2}{*}{\multicolumn{2}{|c|}{ ICT facilities }} & \multicolumn{2}{|c|}{ Akwa-Ibom state } & \multicolumn{2}{|c|}{ Abia state } & \multicolumn{2}{|c|}{ Imo state } & \multicolumn{2}{|l|}{ Total } \\
\hline & & Score & Mean & Score & Mean & Score & Mean & Score & Mean \\
\hline a) & Agricultural journals & 85 & 2.13 & 34 & 1.18 & 65 & 2.41 & 184 & 1.92 \\
\hline b) & Dairies & 56 & 1.4 & 31 & 1.07 & 45 & 1.67 & 132 & 1.38 \\
\hline c) & Agricultural map & 68 & 1.7 & 0 & 0 & 11 & 0.41 & 79 & 0.8 \\
\hline d) & Posters & 105 & 2.63 & 36 & 1.24 & 9 & 0.33 & 150 & 1.56 \\
\hline e) & Newsletters & 76 & 1.9 & 24 & 0.83 & 24 & 0.89 & 124 & 1.29 \\
\hline f) & Annual reports & 129 & 3.23 & 52 & 1.79 & 98 & 3.63 & 279 & 2.90 \\
\hline g) & Media van & 27 & 0.68 & 8 & 0.28 & 1 & 0.07 & 36 & 0.38 \\
\hline h) & Overhead projector & 3 & 0.08 & 0 & 0 & 4 & 0.15 & 7 & 0.07 \\
\hline i) & Telephone (land line) & 20 & 0.5 & 8 & 0.28 & 5 & 0.19 & 33 & 0.34 \\
\hline j) & GSM & 154 & 3.85 & 112 & 3.86 & 122 & 4.52 & 388 & 4.04 \\
\hline k) & E-mail & 26 & 0.65 & 32 & 1.10 & 4 & 0.15 & 62 & 0.65 \\
\hline 1) & Internet & 30 & 0.75 & 28 & 0.97 & 6 & 0.22 & 64 & 0.67 \\
\hline m) & Radio & 174 & 4.35 & 116 & 4 & 130 & 4.81 & 420 & 4.38 \\
\hline n) & Television & 153 & 3.83 & 96 & 3.31 & 128 & 4.74 & 377 & 3.93 \\
\hline o) & Fax & 2 & 0.05 & 20 & 0.69 & 3 & 0.11 & 25 & 0.26 \\
\hline p) & Mobile cinema & 14 & 0.35 & 4 & 0.14 & 4 & 0.15 & 22 & 0.23 \\
\hline q) & Research bulletins & 85 & 2.13 & 92 & 3.17 & 95 & 3.5 & 272 & 2.8 \\
\hline r) & Data processor & 5 & 0.13 & 8 & 0.28 & 2 & 0.07 & 15 & 0.16 \\
\hline s) & Multimedia & 25 & 0.63 & 20 & 0.69 & 5 & 0.19 & 50 & 0.52 \\
\hline t) & Film strips & 33 & 0.83 & 16 & 0.55 & 11 & 0.41 & 60 & 0.63 \\
\hline u) & Audio cassettes & 57 & 1.43 & 28 & 0.97 & 39 & 1.44 & 124 & 1.29 \\
\hline v) & Video recording & 45 & 1.13 & 20 & 0.69 & 4 & 0.15 & 69 & 0.72 \\
\hline w) & Computer & 65 & 1.63 & 48 & 1.66 & 43 & 1.59 & 156 & 1.63 \\
\hline $\mathrm{x})$ & Newspapers & 119 & 2.98 & 92 & 3.17 & 72 & 2.67 & 283 & 2.95 \\
\hline \multicolumn{2}{|c|}{ Grand mean } & & 39.8 & & 32.06 & & 36.44 & & 36.35 \\
\hline \multicolumn{2}{|c|}{ Extent of ICTs usage } & & 1.59 & & 1.28 & & 1.46 & & 1.45 \\
\hline
\end{tabular}


Table 5: Distribution Of The Constraints Of The Respondents To The Use Of ICTs

\begin{tabular}{|c|c|c|c|c|c|}
\hline \multicolumn{2}{|c|}{ Constraints } & \multirow{2}{*}{$\begin{array}{l}\begin{array}{l}\text { Akwa-Ibom } \\
\text { state Frequency }\end{array} \\
13(32.5)^{*}\end{array}$} & \multirow{2}{*}{$\begin{array}{l}\text { Abia state } \\
\text { Frequency } \\
24(82.8)^{*}\end{array}$} & \multirow{2}{*}{$\begin{array}{l}\text { Imo state } \\
\text { Frequency } \\
7(25.9)^{*}\end{array}$} & \multirow{2}{*}{$\begin{array}{l}\text { Total } \\
\text { Frequency } \\
44(45.83)^{*}\end{array}$} \\
\hline & Lack of awareness about ICTs & & & & \\
\hline 2) & Lack of technical expertise necessary for the ICTs & $9(22.5)$ & 28(96.6) & 25(92.6) & $62(64.58)$ \\
\hline 3) & Unstable/unreliable electric power supply & $39(97.5)$ & $20(69)$ & $26(96.3)$ & $85(88.54)$ \\
\hline 4) & Very poor ICTs infrastructure & $13(32.5)$ & 20(69) & $23(85.2)$ & $56(58.33)$ \\
\hline 5) & Lack of money to access the ICTs & $17(42.5)$ & 20(69) & $26(96.3)$ & $63(65.62)$ \\
\hline 6) & Lack of time & $4(10)$ & $8(27.6)$ & $4(14.8)$ & $16(16.67)$ \\
\hline 7) & Religious reasons & - & $4(13.8)$ & $2(7.4)$ & $6(6.25)$ \\
\hline 8) & Low computer literacy & $17(42.5)$ & 20(69) & $26(96.3)$ & $63(65.62)$ \\
\hline 9) & Limited coverage of AM/FM stations and TV signals & $31(77.5)$ & 20(69) & $24(88.9)$ & $75(78.13)$ \\
\hline 10) & Magazines and newspapers are expensive to buy & $11(27.5)$ & 20(69) & $7(25.9)$ & $38(39.58)$ \\
\hline 11) & Very limited access to internet & $36(90)$ & 28(96.6) & $22(81.5)$ & $86(89.58)$ \\
\hline 12) & Limited access to computers & $30(75)$ & $24(82.8)$ & $22(81.5)$ & $76(79.17)$ \\
\hline 13) & Inadequate source of information about the ICTs & $30(31.25)$ & 28(96.6) & $26(96.3)$ & $84(87.50)$ \\
\hline
\end{tabular}

\section{*Figures in parenthesis ( ) are in percentage}

\section{Conclusion}

a) The mean age of the respondents was 40 years. Majority of the respondents $(87.5 \%)$ were married. The mean household size of the respondents was 7 members. More than half of the respondents $(51.04 \%)$ had first degree (B.Sc/B.Agric). The mean working experience was 10 years. The mean income level of the respondents was $\$ 33,875$ per month.

b) The extension agents claimed that twenty-four ICT facilities were available to them but in varying degree.

c) The attitude of the respondents towards the use of ICT facilities was positive (3.11) and therefore would not affect their use of the facilities.

d) The extent of use of ICTs by the BEAs was low (1.45).

e) Thirteen (13) constraints as identified by the BEAs limited their use of ICTs and their major constraint $(89.58 \%)$ was very limited access to the internet.

\section{Recommendations}

Based on the findings of this research, the following recommendations are made:

a) The states' ADPs should endeavor to provide such desirable working conditions that will encourage the BEAs to put in more years of productive service especially since most of the sampled BEAs were in their economically active years.

b) Workshops, conferences and seminars should be organized to train the BEAs in the use of Information Communication Technologies which will improve efficiency in their work.

c) The states' ADPs under study should encourage the use of ICTs by the BEAs either through assignments and works requiring the use of these facilities.

\section{References}

[1]. Adekoya, A.E (2006).Use of ICTs among rural people in Oyo state, Nigeria. Research Journal of Applied Sciences 1(-4): pp 101-105.

[2]. Fillip Jon (2000). Information Communication Technologies in the context of rural development. Overseas development institute, London, p.4.

[3]. Kintumoya, A (1992). "Public libraries and community Information service in Africa", African Journal of Archives and Information Science, pp 33-38.

[4]. Kiplangat (2003): The role of telecentres in the provision of agricultural information for rural development in sub-Saharan Africa. IAALD quarterly bulletin 16(3/4):81-86.

[5]. Michaels, S.I and Van Crowder, L (2001): Discovering the magic Box: Local appropriation of Information and Communication Technologies (ICTs) SDRE, FAO, Rome. 
[6]. Nwachukwu, I (2003); Agricultural Communication, principles and practice; lamb house publishers, Umuahia, Nigeria.

[7]. O'Farrell C. (2007): Information and Communication Technologies (ICTs) for Agricultural and Rural Development in the Carribbean region. FAO publication. www.fao.org.

[8]. Odurukwe S.N (2006): "Impact of Women-in-Agriculture extension programme on women's lives". A report submitted to the Agricultural Development Programme (ADP) office Owerri, Imo-state.

[9]. Richardson, D (1997): The Internet and Rural Development: recommendations for strategy and activity. Food and agricultural Organisation of the United nations, Rome, Italy. Final report pp 42.

[10]. Spore (2004); Information for Agricultural Development in ACD countries; No $110 \mathrm{pp}$ 4-5.

[11]. Yahaya, M.K (2003): "Development Communication" lessons from change and social engineering projects, Corporate graphics Ltd, Ibadan, Nigeria. 